\title{
Pengaruh Green Marketing Mix terhadap Keputusan Pembelian Konsumen Produk Tupperware di Samarinda
}

\author{
Fatur Rahman', Pamasang S. Siburian ${ }^{2}$, Gusti Noorlitaria $\mathbf{A}^{\mathbf{3}}$ \\ Fakultas Ekonomi dan Bisnis Universitas Mulawarman, Indonesia \\ Email: fatur_rahman93@yahoo.com
}

\begin{abstract}
Abstrak
Tujuan dari penelitian ini adalah untuk mengetahui pengaruh variabel Green Product $\left(\mathrm{X}_{1}\right)$, Green Price $\left(\mathrm{X}_{2}\right)$, Green Place $\left(\mathrm{X}_{3}\right)$, Green Promotion $\left(\mathrm{X}_{4}\right)$ terhadap Keputusan Pembelian Produk Tupperware di Samarinda. Berdasarkan hasil analisis diperoleh persamaan regresi linier berganda yaitu $\mathrm{Y}=5,994+0,264 \mathrm{X}_{1}+0,395 \mathrm{X}_{2}+0,383 \mathrm{X}_{3}+0,334 \mathrm{X}_{4}$. Hasil uji $\mathrm{F}$ menunjukkan bahwa nilai $\mathrm{F}_{\text {hitung }}$ $\left(5,748>\mathrm{F}_{\text {tabel }} 2,479\right)$ yang artinya variabel Green Product $\left(\mathrm{X}_{1}\right)$, Green Price $\left(\mathrm{X}_{2}\right)$, Green Place $\left(\mathrm{X}_{3}\right)$, Green Promotion $\left(\mathrm{X}_{4}\right)$ terhadap Keputusan Pembelian Produk Tupperware di Samarinda. Hasil uji $\mathrm{t}$ menujukkan bahwa nilai korelasi parsial variabel Green Product $\left(\mathrm{X}_{1}\right)$ sebesar 0,922 dengan nilai $\mathrm{t}_{\text {hitung }}$ $\left.(2,440)>t_{\text {tabel } 1,985}\right)$ dan signifikan 0.000. Artinya dilihat dari nilai korelasi parsial sebesar 0.922 atau 92,0 \% bahwa variabel Green Product $\left(\mathrm{X}_{1}\right)$, menjadi faktor yang dominan mempengaruhi variabel Keputusan Pembelian (Y).

Kata Kunci: Green Product, Green Price, Green Place, Green Promotion dan Keputusan Pembelian

\section{The Influence of Green Marketing Mix on Consumer Purchase Decision of Tupperware Products in Samarinda}

Abstract

The purpose of this study was to determine the effect of variable Green Product $\left(\mathrm{X}_{1}\right)$, Green Price $\left(\mathrm{X}_{2}\right)$, Green Place $\left(\mathrm{X}_{3}\right)$, Green Promotion $\left(\mathrm{X}_{4}\right)$ to variable Buying Decision $(\mathrm{Y})$ consumer Tupperware on the Samarinda city. Based on the results obtained by analysis of multiple linear regression equation is $\mathrm{Y}=5,994+0,264 \mathrm{X}_{1}+0,395 \mathrm{X}_{2}+0,383 \mathrm{X}_{3}+0,334 \mathrm{X}_{4} \mathrm{~F}$ test results showed that the value of $F\left(5,748>F_{\text {table }} 2,479\right)$, which means variable variable Green Product $\left(\mathrm{X}_{1}\right)$, Green Price $\left(\mathrm{X}_{2}\right)$, Green Place $\left(\mathrm{X}_{3}\right)$, Green Promotion $\left(\mathrm{X}_{4}\right)$ to variable Buying Decision $(\mathrm{Y}) \mathrm{T}$ test results showed that the value of the variable partial correlation Green Product $\left(X_{1}\right)$ of 0,922 with tcount $(2,440)>t$ table $(1,985)$ and significant 0.000 . That is seen from the partial correlation value of 0,922 or $92 \%$ that variable Green Product $\left(\mathrm{X}_{1}\right)$ is a dominant factor influencing buying decision variable $(\mathrm{Y})$.
\end{abstract}

Keywords: Green Product, Green Price, Green Place, Green Promotion and buying decision 


\section{PENDAHULUAN}

Isu mengenai lingkungan hidup menjadi masalah yang sedang disoroti masyarakat luas. Masalah tersebut antara lain pencemaran udara, pencemaran air, serta yang paling fenomenal adalah masalah sampah. Sampah semakin menjadi masalah besar ketika jumlah sampah yang semakin bertamah dan sulit untuk didaur ulang. Berdasarkan data statistik, bahwa peringkat kedua penghasil sampah domestik di Indonesia yaitu produksi sampah plastik yaitu sebesar 5,4 juta ton per tahun (Antara News, 2014). Penggunaan plastik maupun kantong plastik memang semakin bertambah dari tahun ke tahun. Menurut data dari Kementerian Negara Lingkungan Hidup (KLH) menyebutkan bahwa setiap individu rata-rata menghasilkan 0,8 kilogram sampah dalam satuhari dengan kadar 15 persennya adalah plastik (Nursyfani, 2013).

Hal ini dimanfaatkan oleh perusahaan dalam membuka peluang mereka untuk memenuhi kebutuhan dan keinginan dari konsumen yang pola pikirnya sudah mulai berubah. Perusahaan mulai beralih menggunakan bahan baku produk mereka dari bahan yang tidak merusak lingkungan atau yang lebih kita kenal dengan produk ramah lingkungan. Perusahaan yang menerapkan strategi green marketing harus melakukan integrasi pendekatan lingkungan kedalam bauran pemasaran. Riviera (2007) dalam Sumarwan et al. (2012). Pendekatan terhadap kepedulian lingkungan menjadi pembeda antara bauran pemasaran ramah lingkungan dengan bauran pemasaran konvensional. Salah satu produk dari strategi green marketing yang sulit dipilih oleh konsumen adalah peralatan makan. Tupperware muncul dengan inovasi produk yang ramah lingkungan di tengah kesadaran calon konsumen akan pentingnya pelesetarian lingkungan hidup.

Tupperware merupakan perusahaan multinasional yang hadir di lebih dari 120 negara, termasuk di Negara yang memiliki lebih banyak penduduk muslim, seperti Turki, Mesir, Saudi Arabia, Bangladesh, Maroko, Libanon dan Malaysia. Di Indonesia sendiri, Tupperware telah hadir sejak tahun 1991 dan menawarkan solusi untuk produk plastik rumah tangga yang berkualitas tinggi. Tupperware adalah perusahaan yang telah lebih dari 70 tahun berkecimpung dalam pembuatan produk plastik bermutu. Karakteristiknya yang bersifat Eco Green Design, higienis, serta ramah lingkungan. Produk Tupperware terbuat dari bahan plastik berkualitas terbaik, higienis, aman dan sehat serta kedap udara, tidak mengandung zat kimia yang beracun dan sudah memenuhi standar dari beberapa badan dunia seperti FDA (Food and Drug Administration) Amerika, European Food Safety Authority (Eropa) dan Japan Food Safety (Jepang), sehingga selain aman digunakan berkali-kali untuk makanan dan minuman juga ramah lingkungan, higienis serta eco design karena produk Tupperware yang rusak bisa didaur ulang menjadi produk lain seperti bangku plastik, pot tanaman, tempat sampah, dan lain-lain.

\section{LANDASAN TEORI}

\section{Manajemen Pemasaran}

Menurut Kotler dalam Anoraga (2004: 215), mendefinisikan pemasaran adalah suatu proses sosial dan manajerial yang di dalamnya individu dan kelompok mendapatkan apa yang mereka butuhkan dan inginkan dengan menciptakan, menawarkan, dan mempertukarkan produk yang bernilai dengan pihak lain".

\section{Green Marketing Mix}

Pendekatan green marketing pada area produk meningkatkan integrasi dari isu lingkungan pada seluruh aspek Dari aktivitas perusahaan, mulai dari formulasi strategi, perencanaan, penyusunan, sampai produksi dan penyaluran / distribusi dengan pelanggan. Tujuan dari green marketing bukan hanya melihat keuntungan sebagai tujuan utama perusahaan tetapi juga adanya tambahan kepedulian terhadap lingkungan hidup.

\section{Green Product}

Sumarwan et al. (2012:235) mengklarifikasikan produk ramah lingkungan adalah suatu produk yang menggunakan bahan-bahan aman bagi konsumen dan lingkungan, mampu bertahan lama, serta menggunakan bahan dari sumber daya yang dapat diperbaharui.

\section{Green Price}


Tiwari et al. (2011:3) berpendapat bahwa perusahaan yang menerapkan strategi green marketing mix akan menetapkan harga yang lebih tinggi dibandingkan dengan harga produk pesaing.

\section{Green Place}

Queensland Government (2002) mengemukakan perusahaan yang ingin mencapai kesuksesan dalam penjualan produk yang ramah lingkungan seharusnya memposisikan produknya secara luas di pasar sehingga dapat dikenali.

\section{Green Promotion}

Penjualan produk hijau yang cerdas akan dapat menekankan kredibilitas produk yang ramah lingkungan dengan menggunakan sustainable marketing dan juga menggunakan alat praktek komunikasi (Queensland Government, 2002)

\section{Keputusan Pembelian}

Menurut Swastha dan Irawan (2008:118) keputusan pembelian adalah keputusan yang diambil oleh pembeli sebenarnya merupakan kumpulan dari sejumlah keputusan

\section{METODE PENELITIAN}

\section{Definisi Operasional}

\section{Variabel Green Product $\left(\mathrm{X}_{1}\right)$}

Dengan indikator sebagai berikut:

a) Bahan yang digunakan aman bagi konsumen.

b) Tingkat ketahanan produk

c) Menggunakan bahan dari sumber daya yang dapat diperbaharui.

\section{Variabel Green Price $\left(\mathbf{X}_{2}\right)$}

Dengan indikator sebagai berikut:

a) Harga yang lebih tinggi (harga premium)

b) Harga produk yang sebanding dengan kualitasnya.

\section{Variabel Green Place $\left(\mathbf{X}_{3}\right)$}

Dengan indikator sebagai berikut:

a) Letak atau jarak outlet yang strategis

b) Banyaknya outlet yang tersedia.

\section{Variabel Green Promotion $\left(\mathbf{X}_{4}\right)$}

Dengan indikator sebagai berikut:

a) Kredibilitas produk yang ramah lingkungan

b) Promosi menggunakan alat praktek komunikasi

\section{Variabel Keputusan Pembelian (Y)}

Dengan indikator sebagai berikut:

a) Menganalisa keinginan dan kebutuhan

b) Mengidentifikasi alternatif pembelian

c) Mengambil keputusan untuk membeli

d) Perilaku setelah membeli.

\section{Jenis dan Sumber Data}

\section{Jenis Data}

Dalam hal ini data yang digunakan adalah dari hasil jawaban responden atas pertanyaan yang diajukan dalam wawancara, baik secara lisan maupun tertulis.

\section{Sumber Data}

Sumber data dalam penelitian ini adalah:

a. Data Primer

b. Data Sekunder 


\section{Metode Pengumpulan Data}

Metode pengumpulan data primer pada penelitian ini dilakukan dengan menggunakan metode survey yaitu dengan menggunakan kuesioner.

\section{Populasi dan Sampel Populasi}

Populasi dalam penelitian ini adalah konsumen yang ditemui dan menggunakan produk Tupperware di Samarinda dengan jumlah 3.547.

\section{Sampel}

Sampel dari penelitian ini adalah sebagian konsumen yang ditemuidan menggunakan produk dari Tupperware di Samarinda.

Selanjutnya metode pengambilan sampel yang akan digunakan adalah metode Accidental sampling yaitu teknik penentuan sampel berdasarkan kebetulan bertemu dengan peneliti dapat digunakan sebagai sampel, bila dipandang orang yang ditemui itu cocok sebagai sumber data (Sugiyono, 2004:77).

Selanjutnya untuk menentukan banyaknya sampel menurut Ferdinand (2006:229), jika menggunakan variabel independen 3 atau lebih, jumlah sampel dalam besaran minimum penelitian deskriptif adalah dengan menggunakan rumus:

$$
\begin{aligned}
& \mathrm{n}=\frac{Z^{2}}{4(\mathrm{moe})^{2}} \\
& =\frac{1,96^{2}}{4(0,1)^{2}}=96,04(\text { atau dibulatkan 100) }
\end{aligned}
$$

\section{Dimana:}

$$
\begin{aligned}
\mathrm{n}= & \text { jumlah sampel } \\
\mathrm{Z}= & \text { tingkat keyakinan yang dibutuhkan dalam penentuan sampel } \\
& 95 \% . \text { Pada penentuan ini } \mathrm{Z} \text { pada } \mathrm{a}=0,05 \text { adalah1,96. } \\
\text { moe = } & \text { margin of error atau kesalahan maksimal yang bisa ditoleransi, ditentukan sebesar } \\
10 \% . &
\end{aligned}
$$

\section{Metode Analisis Data}

\section{Alat Analisis}

Metode analisis data yang dipakai dalam penelitian ini adalah metode analisis kuantitatif. Dimana untuk mencapai tujuan pertama yaitu menganalisis pengaruh produk, harga, saluran distribusi dan promosi dalam strategi green marketing terhadap keputusan pembelian dalam melakukan pembelian adalah dengan menggunakan analisis regresi berganda (Multiple regresional analysis). Pada penelitian ini menggunakan alat bantu program statistic SPSS for windows.

Model hubungan pilihan konsumen dengan variabel-variabel tersebut dapat disusun dalam fungsi atau persamaan sebagai berikut:

$$
\mathrm{Y}=\mathrm{a}+b_{1} X_{1}+b_{2} X_{2}+b_{3} X_{3}+b_{4} X_{4}+\mathrm{e}
$$

\section{Pengujian Hipotesis \\ Perhitungan Koefisien Korelasi (R)}

Koefisien determinasi digunakan untuk mengetahui kuatnya pengaruh variabel tidak bebas dengan variabel bebas. Semakin besar nilai R, maka semakin tepat model regresi yang dipakai sebagai alat permainan, karena total variasi dapat menjelaskan variabel tidak bebas.

Rangkuti (2003: 168) menyatakan: 


$$
R=\frac{\sqrt{b_{1} \Sigma X_{1} Y+b_{2} \Sigma X_{2} Y+b_{3} \Sigma X_{3} Y+b_{4} \Sigma X_{4} Y}}{\sum Y^{2}}
$$

Keterangan:

$\mathrm{R}=$ Korelasi antara variabel $\mathrm{X}_{1}, \mathrm{X}_{2}, \mathrm{X}_{3}, \mathrm{X}_{4}$, secara bersama- sama dengan variabel.

\section{Perhitungan Koefisien Determinasi $\left(\mathbf{R}^{2}\right)$}

Uji koefisien determinasi $\left(\mathrm{R}_{2}\right)$ digunakan untuk mengukur sebarapa jauh kemampuan model dalam menerangkan keputusan pembelian. Nilai koefisien determinasi adalah antara nol sampai satu nilai $\mathbf{R}_{2}$ yang kecil berarti kemampuan variabel independen sangat terbatas.

\section{Uji f (uji serentak)}

Uji $\mathrm{F}$ merupakan hipotesis guna mengetahui hubungan antara tiga variabel atau lebih. Dengan $\mathrm{k}$ menyatakan bahwa variabel bebas dan $\mathrm{n}=$ ukuran sampel, statistik $\mathrm{F}$ ini didistribusikan dengan pengambilan $\mathrm{dk}$, pengambilan $\mathrm{d}$ dan $\mathrm{dk}$ penyebut $=(\mathrm{n}-\mathrm{k}-1)$. Pada koefisien determinasi berganda hasilnya positif karena menggunakan hasil pengkuadratan. Untuk memperoleh hasil uji $\mathrm{F}$ ini, maka digunakan rumus dari Rangkuti (2003: 219) sebagai berikut:

$$
\text { Fhitung }=\frac{\mathbf{R 2} / \mathbf{K}}{(\mathbf{1}-\mathbf{R} 2 /(\mathbf{n}-\mathbf{k}-\mathbf{1})}
$$

Dengan menggunakan $\mathrm{df}=\mathrm{n}-\mathrm{k}-1$

Dimana:

$\mathrm{R}^{2}=$ koefisien korelasi berganda (determinan)

$\mathrm{n}=$ jumlah anggota sampel

$\mathrm{k}=$ jumlah variabel bebas (independent)

\section{Uji t (Uji Parsial)}

Uji t, yaitu uji untuk mempengaruhi pengaruh variabel-variabel bebas secara parsial terhadap variabel terikat.

Apabila $\mathrm{t}$ hitung $>\mathrm{t}$ table, maka Ho ditolak dan $\mathrm{H} 1$ diterima, dengan demikian variabel bebas dapat menjelaskan variabel terikat yang ada dalam model. Sebaliknya apabila $t$ hitung $<\mathrm{t}$ table, maka Ho diterima dan H1 ditolak, dengan demikian variabel bebas tidak dapat menjelaskan variabel terikat atau dengan kata lain tidak ada pengaruh antara dua variabel yang diuji (Algifari, 2000:32)

\section{HASIL PENELITIAN}

\section{Demografi Responden}

\section{Jenis Kelamin Responden}

Dari 100 orang responden, jumlah responden yang berjenis kelamin perempuan lebih mendominasi daripada yang berjenis kelamin laki-laki. Hal ini terlihat pada jumlah laki-laki sebanyak 24 orang sedangkan yang berjenis kelamin perempuan sebanyak 76 orang.

\section{Usia Responden}

Usia responden dalam penelitian ini kebanyakan berusia antara 20-30 tahun yaitu sebanyak 59 orang (59\%). Sementara responden yang berusia antara 31-40 tahun adalah sebanyak 33 orang (33\%), yang berusia antara 41-50 tahun sebanyak 7 orang (7\%), sedangkan yang berusia lebih dari 50 tahun hanya 1 orang $(1 \%)$.

\section{Jenis Pekerjaan Responden}


Jenis pekerjaan yang dimiliki oleh responden yang menjadi sampel dalam penelitian inilebuih banyak bekerja sebagai karyawan swasta yaitu sebnayk 43 orang (43\%), responden yang bekerja sebagai PNS sebanyak 20 orang (20\%), yang bekerja sebagai wiraswasta sebesar 9 orang (9\%), sedangkan yang masih sebagai mahasiswa sebanyak 28 orang $(28 \%)$.

\section{Hasil Analisis \\ Uji Validitas}

Setelah mengumpulkan kusioner dari responden, kemudian dilakukan uji validitas kembali terhadap data yang diperoleh. Uji validitas menggunakan Pearson yang dibandingkan dengan $\mathrm{r}$ tabel, di mana $\mathrm{r}$ tabel untuk $\mathrm{N}$ sebanyak 30 pada tingkat keyakinan $95 \%$ adalah sebesar 0,361 . Nilai $\mathrm{R}$ hitung untuk semua item adalah di atas $r$ tabel yaitu sebesar 0,361. Hal ini menunjukkan bahwa semua item yang digunakan untuk mengukur variabel penelitian adalah valid

\section{Uji Realibilitas}

Kriteria suatu instrument dikatakan reliabel dengan menggunakan teknik ini, bila Cronbach alpha $>$ 0,6 namun sebaliknya apabila Cronbach alpha $<0,6$ hal ini menunjukan tidak adanya konsistensi. Hasil penelitian reliabilitas variabel bebas maupun variabel terikat dalam penelitian ini menunjukka Cronbach Alpha yang lebih besar dari 0,6 sehingga dapat disimpulkan seluruh variabel bebas dalam penelitian ini reliabel.

\section{Rekapitulasi Jawaban Responden}

Berikut ini adalah hasil output kuisioner yang diberikan kepada responden sebagai konsumen akhir Tupperware di Samarinda:

\section{Variabel Produk $\left(\mathbf{X}_{1}\right)$, indikatornya adalah sebagai berikut:}

1) Bahan baku yang digunakan oleh Tupperware aman bagi konsumen

Tabel 4.4. Rekapitulasi frekuensi jawaban responden indikator $\mathrm{X}_{1.1}$

\begin{tabular}{cccc} 
Bobot & Jawaban Responden & Frekuensi & Presentase $(\%)$ \\
\hline 1 & Sangat Tidak Setuju & - & - \\
2 & Tidak Setuju & - & - \\
3 & Cukup Setuju & 26 & $26 \%$ \\
4 & Setuju & 61 & $61 \%$ \\
5 & Sangat Setuju & 13 & $13 \%$ \\
\hline & Total & 100 & $100 \%$ \\
\hline
\end{tabular}

Sumber: Data Diolah

2) Tupperware merupakan produk yang memiliki ketahanan produk yang tidak diragukan

Tabel 4.5. Rekapitulasi frekuensi jawaban responden indikator $\mathrm{X}_{1.2}$

\begin{tabular}{cccc}
\hline Bobot & Jawaban Responden & Frekuensi & Presentase (\%) \\
\hline 1 & Sangat Tidak Setuju & - & - \\
2 & Tidak Setuju & - & - \\
3 & Cukup Setuju & 12 & $12 \%$ \\
4 & Setuju & 65 & $65 \%$ \\
5 & Sangat Setuju & 23 & $23 \%$ \\
\hline
\end{tabular}

Sumber: Data Diolah

3) Menggunakan bahan dari sumber daya yang dapat diperbaharui.

Tabel 4.6. Rekapitulasi frekuensi jawaban responden indikator $\mathrm{X}_{1.3}$

\begin{tabular}{cccc}
\hline Bobot & Jawaban Responden & Frekuensi & Presentase (\%) \\
\hline 1 & Sangat Tidak Setuju & - & - \\
2 & Tidak Setuju & - & - \\
3 & Cukup Setuju & 19 & $19 \%$ \\
4 & Setuju & 57 & $57 \%$
\end{tabular}




\begin{tabular}{cccc}
\hline Bobot & Jawaban Responden & Frekuensi & Presentase (\%) \\
\hline 5 & Sangat Setuju & 24 & $24 \%$ \\
\hline & Total & 100 & $100 \%$ \\
\hline
\end{tabular}

\section{Variabel Harga $\left(\mathbf{X}_{2}\right)$, indikatornya adalah sebagai berikut:}

1) Harga produk yang ditawarkan lebih tinggi (harga premium)

Tabel 4.7. Rekapitulasi frekuensi jawaban responden indikator $X_{2.1}$

\begin{tabular}{cccc}
\hline Bobot & Jawaban Responden & Frekuensi & Presentase (\%) \\
\hline 1 & Sangat Tidak Setuju & - & - \\
2 & Tidak Setuju & 7 & $7 \%$ \\
3 & Cukup Setuju & 19 & $19 \%$ \\
4 & Setuju & 53 & $53 \%$ \\
5 & Sangat Setuju & 21 & $21 \%$ \\
& Total & 100 & $100 \%$ \\
\hline
\end{tabular}

Sumber: Data Diolah

2) Harga produk sebanding dengan kualitasnya.

Tabel 4.8. Reakapitulasi frekuensi jawaban responden indikator $\mathrm{X}_{2.2}$

\begin{tabular}{cccc}
\hline Bobot & Jawaban Responden & Frekuensi & Presentase (\%) \\
\hline 1 & Sangat Tidak Setuju & - & - \\
2 & Tidak Setuju & - & - \\
3 & Cukup Setuju & 8 & $8 \%$ \\
4 & Setuju & 62 & $62 \%$ \\
5 & Sangat Setuju & 30 & $30 \%$ \\
\hline
\end{tabular}

Sumber: Data Diolah

\section{Variabel Tempat $\left(\mathrm{X}_{3}\right)$, indikatornya adalah sebagai berikut:}

1) Letak atau jarak outlet yang strategis

Tabel 4.8. Rekapitulasi frekuensi jawaban responden indikator $\mathrm{X}_{3.1}$

\begin{tabular}{cccc}
\hline Bobot & Jawaban Responden & Frekuensi & Presentase (\%) \\
\hline 1 & Sangat Tidak Setuju & - & - \\
2 & Tidak Setuju & 1 & $1 \%$ \\
3 & Cukup Setuju & 10 & $10 \%$ \\
4 & Setuju & 56 & $56 \%$ \\
5 & Sangat Setuju & 33 & $33 \%$ \\
\hline
\end{tabular}

Sumber: Data Diolah

2) Banyaknya outlet yang tersedia

Tabel 4.9. Rekapitulasi frekuensi jawaban responden indikator $\mathrm{X}_{3.2}$

\begin{tabular}{cccc}
\hline Bobot & Jawaban Responden & Frekuensi & Presentase (\%) \\
\hline 1 & Sangat Tidak Setuju & - & - \\
2 & Tidak Setuju & - & - \\
3 & Cukup Setuju & 7 & $7 \%$ \\
4 & Setuju & 65 & $65 \%$ \\
5 & Sangat Setuju & 28 & $28 \%$ \\
\hline
\end{tabular}

Sumber: Data Diolah

Variabel Promosi $\left(\mathrm{X}_{4}\right)$, indikatornya adalah sebagai berikut:

1) Kredibilitas produk yang ramah lingkungan 
Tabel 4.10: Rekapitulasi frekuensi jawaban responden indikator $\mathrm{X}_{4.1}$

\begin{tabular}{c|ccc}
\hline Bobot & Jawaban Responden & Frekuensi & Presentase (\%) \\
\hline 1 & Sangat Tidak Setuju & - & - \\
2 & Tidak Setuju & - & - \\
3 & Cukup Setuju & 5 & $5 \%$ \\
4 & Setuju & 62 & $62 \%$ \\
5 & Sangat Setuju & 33 & $33 \%$ \\
\hline
\end{tabular}

Sumber: Data Diolah

2) Promosi dengan menggunakan alat praktek komunikasi

Tabel 4.11. Rekapitulasi frekuensi jawaban responden indikator $\mathrm{X}_{4.2}$

\begin{tabular}{cccc}
\hline Bobot & Jawaban Responden & Frekuensi & Presentase (\%) \\
\hline 1 & Sangat Tidak Setuju & - & - \\
2 & Tidak Setuju & - & - \\
3 & Cukup Setuju & 12 & $12 \%$ \\
4 & Setuju & 68 & $68 \%$ \\
5 & Sangat Setuju & 20 & $20 \%$ \\
\hline
\end{tabular}

Sumber: Data Diolah

\section{Variabel Keputusan Pembelian (Y), indikatornya adalah sebagai berikut:}

1) Konsumen akan menganalisa kebutuhan dan keinginan sebelum melakukan pembelian

Tabel 4.12: Rekapitulasi frekuensi jawaban responden indikator $\mathrm{Y}_{1}$

\begin{tabular}{cccc}
\hline Bobot & Jawaban Responden & Frekuensi & Presentase (\%) \\
\hline 1 & Sangat Tidak Setuju & - & - \\
2 & Tidak Setuju & - & - \\
3 & Cukup Setuju & 13 & $13 \%$ \\
4 & Setuju & 66 & $66 \%$ \\
5 & Sangat Setuju & 21 & $21 \%$ \\
\hline
\end{tabular}

Sumber: Data Diolah

2) Konsumen perlu mengidentifikasi alternative pembelian sebelum melakukan transaksi

Tabel 4.13. Rekapitulasi frekuensi jawaban responden indikator $\mathrm{Y}_{2}$

\begin{tabular}{c|c|c|c}
\hline Bobot & Jawaban Responden & Frekuensi & Presentase (\%) \\
\hline 1 & Sangat Tidak Setuju & - & - \\
2 & Tidak Setuju & - & - \\
3 & Cukup Setuju & 11 & $11 \%$ \\
4 & Setuju & 71 & $71 \%$ \\
5 & Sangat Setuju & 18 & $18 \%$ \\
\hline
\end{tabular}

Sumber: Data Diolah

3) melakukan analisa dan identifikasi, konsumen akan mengambil keputusan untuk membeli.

Tabel 4.14. Rekapituilasi frekuensi jawaban responden indikator $\mathrm{Y}_{3}$

\begin{tabular}{cccc}
\hline Bobot & Jawaban Responden & Frekuensi & Presentase (\%) \\
\hline 1 & Sangat Tidak Setuju & - & - \\
2 & Tidak Setuju & - & - \\
3 & Cukup Setuju & 10 & $10 \%$ \\
4 & Setuju & 72 & $72 \%$ \\
5 & Sangat Setuju & 18 & $18 \%$ \\
\hline
\end{tabular}

Sumber: Data Diolah 
4) Kepuasan dalam bertransaksi dan penggunaan produk akan berpengaruh terhadap perilaku setelah membeli.

Tabel 4.15: Rekapitulasi frekuensi jawaban responden indikator $\mathrm{Y}_{4}$

\begin{tabular}{cccc}
\hline Bobot & Jawaban Responden & Frekuensi & Presentase (\%) \\
\hline 1 & Sangat Tidak Setuju & - & - \\
2 & Tidak Setuju & - & - \\
3 & Cukup Setuju & 2 & $2 \%$ \\
4 & Setuju & 69 & $69 \%$ \\
5 & Sangat Setuju & 29 & $29 \%$ \\
\hline
\end{tabular}

Sumber: Data Diolah

\section{HASIL DAN PEMBAHASAN}

Regresi Linier Berganda

Analisis regresi linier berganda dilakukan dengan bantuan program Statistical Product and Service Solution (SPSS) Versi 20.0. Persamaan model regresi linier berganda yang diperoleh dari hasil perhitungan adalah sebagai berikut:

\section{Hasil Regresi Linier Berganda}

\begin{tabular}{llll}
\hline Variabel bebas & Koefisien Regresi & T Hitung & Sig \\
\hline Constanta & 5,994 & 2,838 & 0,006 \\
Green product & 0,264 & 2,440 & 0,017 \\
Green price & 0,395 & 2,416 & 0,046 \\
Green place & 0,383 & 2,398 & 0,018 \\
Green promotion & 0,334 & 2,006 & 0,048 \\
Multiple R=0,922 & F hitung $=5,748$ & T tabel $=1,985$ & \\
\hline R Squre $=0,850$ & Signifikan $=0,000$ & & \\
\hline Sumber: Data Diolah & & &
\end{tabular}

Jika dilihat dari tabel 4.18 di atas, dengan nilai $\alpha=5 \%(0,05)$ maka diperoleh persamaan regresi linear berganda sebagai berikut:

$Y=5,994+0,264 X_{1}+0,095 X_{2}+0,383 X_{3}+0,334 X_{4}$

\section{Uji R dan Uji $\mathbf{R}^{2}$}

Berdasarkan ringkasan hasil regresi linier berganda pada tabel 4.18 menunjukkan nilai $\mathrm{R}=$ 0,922 yang artinya terdapat hubungan positif dan kuat antara pengaruh green product $\left(\mathrm{X}_{1}\right)$, green price $\left(\mathrm{X}_{2}\right)$, green place $\left(\mathrm{X}_{3}\right)$, dan green promotion $\left(\mathrm{X}_{4}\right)$ terhadap variabel dependen keputusan pembelian (Y) dan mempunyai korelasi sebesar $92 \%$. Dari hasil tersebut diperoleh nilai koefisien determinasi $\left(\mathrm{R}^{2}\right)$ sebesar $85 \%$ terhadap variabel terikat yaitu keputusan pembelian. Sisanya sebesar $15 \%$ dipengaruhi oleh faktor lain yang tidak diteliti dalam penelitian ini.

\section{Uji F (Simultan)}

Uji $\mathrm{f}$ ini dilakukan dengan membandingkan nilai $\mathrm{f}_{\text {hitung }}$ dengan $\mathrm{f}_{\text {tabel }}$. Pengujian dilakukan pada level of signifikan $95 \% \alpha=0,05$ dengan degree of freedom $(\mathrm{df}) \mathrm{n}-\mathrm{k}-1=100-4-1=95$

TABEL 4.19. Hasil Uji Simultan (Uji f)

\begin{tabular}{|c|c|c|c|c|c|}
\hline $\begin{array}{c}\text { Koefisien } \\
\text { Korelasi (R) }\end{array}$ & $\begin{array}{c}\text { Koefisien } \\
\text { Determinasi }\left(\mathrm{R}^{2}\right)\end{array}$ & $\mathrm{f}_{\text {hitung }}$ & $\mathrm{f}_{\text {tabel }}$ & Sig & Keterangan \\
\hline 0,922 & 0,850 & 5,748 & 2,479 & 0,000 & Signifikan \\
\hline
\end{tabular}

Sumber: Data Diolah 


\section{Uji t (Parsial)}

\section{Variabel Green Product $\left(\mathbf{X}_{1}\right)$}

Dari hasil perhitungan diperoleh $t_{\text {hitung }}$ sebesar 2,440 > dibandingkan dengan $t_{\text {tabel }}$ sebesar 1,985 atau dengan angka signifikan 0,017 dengan $\alpha$ 0,05. Maka $t_{\text {hitung }}>t_{\text {tabel }} \mathrm{H}_{0}$ ditolak dan $\mathrm{H}_{1}$ diterima.

\section{Variabel Green Price $\left(\mathbf{X}_{2}\right)$}

Dari hasil perhitungan diperoleh $t_{\text {hitung }}$ sebesar 2,416 > dibandingkan dengan $t_{\text {tabel }}$ sebesar 1,985 atau dengan angka signifikan 0,046 dengan $\alpha$ 0,05. Maka $\mathrm{t}_{\text {hitung }}>\mathrm{t}_{\text {tabel }} \mathrm{H}_{0}$ ditolak dan $\mathrm{H}_{1}$ diterima.

\section{Variabel Green Place $\left(\mathrm{X}_{3}\right)$}

Dari hasil perhitungan diperoleh $t_{\text {hitung }}$ sebesar 2,398 > dibandingkan dengan $t_{\text {tabel }}$ sebesar 1,985 atau dengan angka signifikan 0,018 dengan $\alpha$ 0,05. Maka $t_{\text {hitung }}>t_{\text {tabel }} \mathrm{H}_{0}$ ditolak dan $\mathrm{H}_{1}$ diterima.

\section{Variabel Green Promotion $\left(\mathbf{X}_{4}\right)$}

Dari hasil perhitungan diperoleh $t_{\text {hitung }}$ sebesar 2,006 > dibandingkan dengan $t_{\text {tabel }}$ sebesar 1,985 atau dengan angka signifikan 0,048 dengan $\alpha$ 0,05. Maka $t_{\text {hitung }}>t_{\text {tabel }} \mathrm{H}_{0}$ ditolak dan $\mathrm{H}_{1}$ diterima.

\section{Pembahasan}

Berdasarkan hasil penelitian ini dapat dilihat bahwa hasil perhitungan variabel green product $\left(\mathrm{X}_{1}\right)$ diperoleh $\mathrm{t}_{\text {hitung }}$ sebesar 2,440 lebih besar dibandingkan $\mathrm{t}_{\text {tabel }}$ 1,985. Hal ini membuktikan bahwa produk yang ditawarkan oleh Tupperware memang memiliki keunggulan dari segi bentuk dan ketahanan produk yang dirasakan oleh konsumen sehingga variabel green product berpengaruh positif dan signifikan terhadap keputusan pembelian. Kemudian hasil perhitungan variabel green price $\left(\mathrm{X}_{2}\right)$ diperoleh $t_{\text {hitung }}$ sebesar 2,416 lebih besar dibandingkan $t_{\text {tabel }} 1,985$. Hal ini membuktikan bahwa harga Tupperware yang berkisar dari harga Rp. 35.000,00 - Rp. 750.000,00 sebanding dengan produk yang ditawarkan kepada konsumen, harga premium tersebut justru menjadi nilai tambah dari Tupperware dengan kualitas produk yang tinggi, sehingga variabel green price berpengaruh positif dan signifikan terhadap keputusan pembelian. Selanjutnya variabel green place $\left(\mathrm{X}_{3}\right)$ diperoleh $\mathrm{t}_{\text {hitung }}$ sebesar 2,398 lebih besar dibandingkan $t_{\text {tabel }} 1,985$. Hal ini membuktikan letak outlet yang strategis menjadi faktor penting dalam proses pemasaran, outlet pusat Tupperware yang berada di Jalan Ahmad Yani (Pemuda) dan outlet cabang yang tersebar di Samarinda mempermudah konsumen untuk melakukan transaksi pembelian, kemudian outlet pusat memberikan nuansa yang bersih dan rapi sehingga menambah kenyamanan konsumen untuk berbelanja. Dan yang terakhir adalah variabel green promotion diperoleh $t_{\text {hitung }}$ sebsar 2,006 lebih besar dibandingkan $\mathrm{t}_{\text {tabel }}$ 1,985. Hal ini membuktikan bahwa promosi yang dilakukan oleh Tupperware berhasil menarik minat konsumen untuk memutuskan membeli produk Tupperware, promosi yang dilakukan adalah dengan menggunakan alat praktek komunikasi seperti media televisi, koran kemudian informasi dari mulut ke mulut. sehingga variabel green promotion berpengaruh positif dan signifikan terhadap keputusan pembelian

\section{SIMPULAN}

Berdasarkan hasil analisis dan pembahasan di bab sebelumnya, maka dapat ditarik kesimpulan sebagai berikut:

1) Dari analisis regresi linear berganda diperoleh persamaan, yaitu:

$$
Y=5,994+0,264 X_{1}+0,395 X_{2}+0,383 X_{3}+0,334 X_{4}
$$

Dari persamaan diatas dapat diketahui bahwa variabel bebas green product $\left(\mathrm{X}_{1}\right)$, green price $\left(\mathrm{X}_{2}\right)$, green place $\left(\mathrm{X}_{3}\right)$, dan green promotion $\left(\mathrm{X}_{4}\right)$ mempunyai pengaruh yang positif dan signifikan terhadap variabel dependen keputusan pembelian (Y) konsumen akhir Tupperware di Samarinda.

2) Nilai koefisien korelasi $(\mathrm{R})$ diperoleh sebesar 0,922 yang artinya terdapat hubungan positif dan kuat antara variabel bebas green product $\left(\mathrm{X}_{1}\right)$, green price $\left(\mathrm{X}_{2}\right)$, green place $\left(\mathrm{X}_{3}\right)$, dan green promotion $\left(\mathrm{X}_{4}\right)$ terhadap variabel dependen keputusan pembelian $(\mathrm{Y})$ konsumen akhir Tupperware di Samarinda.

3) Nilai koefisien determinasi $\left(\mathrm{R}^{2}\right)$ menunjukkan bahwa variabel bebas green product $\left(\mathrm{X}_{1}\right)$, green price $\left(\mathrm{X}_{2}\right)$, green place $\left(\mathrm{X}_{3}\right)$, dan green promotion $\left(\mathrm{X}_{4}\right)$ mampu menjelaskan terhadap variabel 
dependen keputusan pembelian (Y) konsumen akhir Tupperware di Samarinda sebesar 85\% sedangkan sisanya sebesar $15 \%$ dipengaruhi oleh faktor-faktor lain.

4) Dari Hasil pengujian secara parsial (Uji t), disimpulkan bahwa:

a) Variabel Green Product $\left(\mathrm{X}_{1}\right)$ memberikan pengaruh yang signifikan terhadap keputusan pembelian. Hal ini terlihat dari $t_{\text {hitung }}>t_{\text {tabel }}$ atau 2,440 $>1,985$ dan juga didukung oleh nilai signifikasi $0,017<0,05$.

b) Variabel Green Price $\left(\mathrm{X}_{2}\right)$ memberikan pengaruh yang signifikan terhadap keputusan pembelian. Hal ini terlihat dari $\mathrm{t}_{\text {hitung }}>\mathrm{t}_{\text {tabel }}$ atau $2,416>1,985$ dan juga didukung nilai signifikasi $0,046<0,05$.

c) Variabel Green Place $\left(\mathrm{X}_{3}\right)$ memberikan pengaruh yang signifikan terhadap keputusan pembelian. Hal ini terlihat dari $t_{\text {hitung }}>t_{\text {tabel }}$ atau 2,398 $>1,985$ dan juga didukung nilai signifikasi $0,018<0,05$.

d) Variabel Green Promotion $\left(\mathrm{X}_{4}\right)$ memberikan pengaruh yang signifikan terhadap keputusan pembelian. Hal ini terlihat dari $t_{\text {hitung }}>t_{\text {tabel }}$ atau 2,006 > 1,985 dan juga didukung nilai signifikasi $0,046<0,05$.

5) Dari hasil pengujian secara simultan (Uji f) disimpulkan bahwa, $\mathrm{f}_{\text {hitung }}>\mathrm{f}_{\text {tabel }}$ atau 5,748 $>2,479$ dengan signifikasi 0,000 yang menunjukkan bahwa variable bebas green product $\left(\mathrm{X}_{1}\right)$, green price $\left(\mathrm{X}_{2}\right)$, green place $\left(\mathrm{X}_{3}\right)$, dan green promotion $\left(\mathrm{X}_{4}\right)$ mempunyai pengaruh yang positif dan signifikan terhadap variabel dependen keputusan pembelian (Y) konsumen akhir Tupperware di Samarinda.

\section{SARAN}

Untuk melengkapi hasil dari penelitian ini, maka penulis akan memberikan beberapa saran, yaitu:

1) Tupperware sudah memiliki produk-produk yang bervariasi dan diharapkan Tupperware untuk selalu berinovasi dan selalu mendengarkan apa yang diinginkan oleh Konsumen

2) Promosi yang dilakukan dirasa masih kurang sehingga konsumen kurang memiliki wawasan yang lebih luas terhadap produk Tupperware. Tuperware juga diharapkan ikut ambil peran dalam mensponsori kegiatan-kegiatan lingkungan dan sosial yang ada di Samarinda.

3) Dikarenakan dalam penelitian ini masih menemui keterbatasan, sehingga bagi peneliti selanjutnya diharapkan dapat meneliti dengan variabel-variabel lain dan perlu digunakan responden yang lebih luas dan beragam agar memperoleh hasil yang lebih bervariatif yang dapat berpengaruh terhadap keputusan pembelian

\section{DAFTAR PUSTAKA}

Antara News. 2014. Survei WWF Masyarakat Minta Caleg Peduli Lingkungan. http://www.antaranews.com/berita/418734/ diakses tanggal 22 Februari 2016.

Ayu, Nusryamsi. 2013. Pengaruh Strategi Green Marketing Pada Bauran Pemasaran Terhadap Keputusan Konsumen Dalam Membeli Rumah Di Perumahan PT. Asta Karya [Ekanbaru. FE UR. Pekanbaru.

Dwi, Risna dan Kumadji, Srikandi. 2015. Pengaruh Green Marketing Terhadap Minat Beli Serta Dampaknya Pada Keputusan Pembelian (Survei Pada Konsumen Non-Member Tupperware di Kota Malang). FIA UB. Malang.

Hashem, Tareq N \& Al - Rifai. The influence of applying green marketing mix by chemical industries companies in three Arab States in West Asia on consumer's mental image. Vol. 2 No. 3

Junaedi, M.F.S. 2005. Pengaruh Kesadaran Lingkungan Pada Niat Beli Produk Hijau: Studi Perilaku Konsumen Berwawasan Lingkungan. Benefit, vol. 9, No. 2, Desember, pp :189-201.

Kotler, Philip dan Amstrong, Gary. 2008. Prinsip-prinsip Pemasaran, Edisi ke XII, jilid kedua. Erlangga. Jakarta.

Lozada, H.R. 2000. Ecological Sustainability and Marketing Strategy: Review and Implication. Seton Hall University. 
Queensland Government, 2002. Green Marketing- The Competitive Advantage of Suistainability. www.epa.qld.gov.au/sustainable_industries.

Riyadi, Minggar. 2012. Analisis Pengaruh Bauran Pemasaran Terhadap Keputusan Pembelian Pelumas Sepeda Motor Endure 4T Studi Pada Pelumas Sepeda Motor Endure 4T Pertamina Jawa Bagian Tengah. FEB UDN.

Romadon, Yusuf dan Kumadji, Srikandi. 2014. Pengaruh Green Marketing Terhadap Brand Image Dan Struktur Keputusan Pembelian. FIA UB. Malang.

Seftipani, Riska dan Achmadi, Fuad. 2014. Pengaruh Green Marketing, Pengetahuan Dan Minat Membeli Terhadap Keputusan Pembelian. FTP UB. Malang.

Stevanie, Cicilia. 2012. Pengaruh Green Marketing Terhadap Nilai Yang Dipersepsikan Dalam Keputusan Pembelian Pada Ades (Studi Kasus Pada Mahasiswa/I Fakultas Komunikasi Dan Bisnis Telkom University). Bandung.

Sugiyono, 2000. Metode Penelitian Bisnis. Cetakan Kedua. CV. Alfa Beta. Bandung.

Suharno dan Sutarso, Yudi. 2013. Marketing in Practice. CV. Sary Card. Samarinda.

Tjiptono, F. 2008. Strategi Pemasaran, Edisi ketiga. Andi offset. Yogyakarta.

Tupperware Indonesia. 2013. Produk-produk Tupperware. www.tuperware.co.id diakses pada tanggal 8 Februari 2017 